\title{
Effects of variation in egg energy and exogenous food on larval development in congeneric sea urchins
}

\author{
Justin S. McAlister ${ }^{1,2, *}$, Amy L. Moran ${ }^{1,3}$ \\ ${ }^{1}$ Department of Biological Sciences, Clemson University, Clemson, South Carolina 29634, USA \\ ${ }^{2}$ Present address: Department of Biology, College of the Holy Cross, Worcester, Massachusetts 01610, USA \\ ${ }^{3}$ Present address: Department of Biology, University of Hawaii at Manoa, Honolulu, Hawaii 96822, USA
}

\begin{abstract}
Planktotrophic larvae of marine invertebrates develop and grow by utilizing a combination of endogenous materials contained in the egg and exogenous food consumed during development. In general, larger eggs contain more reserves for morphogenesis and metabolism than smaller eggs. Interspecific comparisons among planktotrophic echinoderms have generally found that increased maternal provisioning decreases the length of development in the plankton, leading to the widely held idea that large eggs are likely to be selectively favored in low-food or high-mortality environments. Despite long interest in these patterns, however, few studies have examined how exogenous and endogenous supplies interactively affect larval development in phylogenetically controlled and environmentally relevant contexts. We investigated the direct and interactive effects of both endogenous egg materials and exogenous food supply on larval performance of 3 closely related tropical sea urchin species (Echinometra spp.). We found that egg size was positively correlated with egg energy among these 3 species, and that larvae of species with larger (and more energy-rich) eggs developed more rapidly than those from smaller (and lower-energy) eggs. Likewise, across species, larvae fed higher rations grew more rapidly than those fed less. Length of development was most strongly affected by food level in the species with the smallest eggs. Compared to the lowest food treatment, satiating levels shortened development by 9,7 , and 4 d for E. vanbrunti, E. lucunter, and E. viridis, respectively (listed in order of increasing egg energy). Our study supports the hypothesis that the growth and development of larvae are more strongly affected by exogenous food availability when they develop from lower-energy eggs than when larvae develop from energy-rich eggs.
\end{abstract}

KEY WORDS: Larvae · Egg size $\cdot$ Egg energy $\cdot$ Egg composition · Growth · Plankton · Echinoid · Echinometra spp.

Resale or republication not permitted without written consent of the publisher

\section{INTRODUCTION}

The life-history characteristic of free-spawning marine invertebrates that has received more attention than perhaps any other is the amount of energy mothers invest in individual eggs. Egg energy is most often not measured directly, but instead is inferred from egg size, which is a reasonable (though imperfect) es- timator (Emlet et al. 1987, McEdward \& Carson 1987, McEdward \& Coulter 1987, Jaeckle 1995, McEdward \& Morgan 2001, Sewell \& Manahan 2001, Moran \& McAlister 2009). Egg size, because of its relationship with energy, is correlated with a number of important life history traits including larval developmental mode (Thorson 1950, Strathmann 1985, Emlet et al. 1987, Levin \& Bridges 1995), length of larval develop- 
ment (Thorson 1950, Vance 1973a,b, Strathmann 1985, Hadfield \& Miller 1987, Sinervo \& McEdward 1988, Wray \& Raff 1991), starvation resistance (Anger 1995, Bridges \& Heppell 1996), larval morphology (McEdward 1986, Bertram \& Strathmann 1998), size at metamorphosis (Strathmann 1985, Emlet et al. 1987), and juvenile growth and survival (Emlet \& Hoegh-Guldberg 1997, Marshall et al. 2003).

Most marine invertebrates fall into 1 of 2 developmental modes, lecithotrophy or planktotrophy (Strathmann \& Vedder 1977, Turner \& Lawrence 1979, McClintock \& Pearse 1986, McEdward 1991, McEdward \& Chia 1991, Eckelbarger 1994, Herrera et al. 1996, Wray 1996, McEdward \& Janies 1997, Miner et al. 2005, Allen \& Podolsky 2007). Larvae of lecithotrophic species develop from eggs containing all the energy and material that larvae need to reach metamorphosis. Planktotrophic larvae, in contrast, need to acquire at least some of their structural material and energy from exogenous sources, and there is considerable interspecific variation in the amount of energy contained in planktotrophic eggs (McEdward \& Carson 1987, McEdward \& Coulter 1987, McEdward \& Morgan 2001). Both of these developmental modes, as well as intermediate types of development (e.g. facultative planktotrophy; Allen \& Pernet 2007, Collin 2012, Knott \& McHugh 2012) occur among the echinoid echinoderms (sea urchins and their allies). Echinoids, as a group, are thus particularly suited to examining the relationships between egg energy and larval development and growth, and they have been the focus of most previous work in these areas (Emlet et al. 1987).

Models of life history evolution have generally assumed that, all else being equal, the length of larval development is inversely correlated with the size of the egg from which a larva develops (Vance 1973a,b, Christiansen \& Fenchel 1979, Caswell 1981, Perron \& Carrier 1981, Grant 1983, Strathmann 1985, Roughgarden 1989, Havenhand 1995, McEdward 1997, Levitan 2000). Energy-rich eggs are thought to evolve in the context of selection to shorten development or alleviate starvation in dangerous, patchy, unpredictable, or characteristically food-poor environments (Vance 1973a, Strathmann 1985, Emlet et al. 1987, Lessios 1990, Herrera et al. 1996, McEdward 1996, 1997, Levitan 2000, Allen et al. 2006). More recent work supports the idea that instead of an inversely linear relationship between egg size and length of development, this relationship may instead be better described as inversely proportional (Levitan 2000, Allen 2012). Experimental or evolutionary changes in egg size may thus have a greater impact on the length of larval development for species with smaller eggs, whereas juvenile size may be affected more for species with larger eggs (Allen 2012). Broad phylogenetic comparisons and experimental embryology have thus contributed much to our understanding of this aspect of life history theory. Careful study of closely related species within a given developmental mode provides another way to examine the relationship between egg size and larval development.

Furthermore, among feeding larvae, comparative studies are broadly consistent with the idea that larger (and presumably more energy-rich) eggs shorten development. In general, planktotrophic echinoids with larger eggs reach metamorphosis more quickly than species with smaller eggs (Emlet 1995), though there is no clear relationship between egg size and size at metamorphosis (such effects may be masked by other factors both phylogenetic and experimental; Emlet et al. 1987, Herrera et al. 1996). Intraspecific comparisons of whole- and half-sized larvae (the latter produced via blastomere separations) also generally find that larvae from larger eggs reach metamorphosis sooner (Sinervo \& McEdward 1988, Levitan 2000, Alcorn \& Allen 2009, Allen 2012; but see Hart 1995, Emlet \& Hoegh-Guldberg 1997, Allen et al. 2006 for exceptions). Larvae of most planktotrophic echinoids also grow more rapidly and/or to larger sizes when food is abundant (Hart 1995, Miller \& Emlet 1999, Allen et al. 2006). However, while the effects of egg energy and exogenous food have been separately described, much less is known about how the two interact (Alcorn \& Allen 2009, Allen 2012). Thus, interspecific comparisons among closely related taxa can also shed light on whether there are interactive effects between egg energy and exogenous food availability that support the idea that large, energy-rich eggs act to reduce a larva's reliance on exogenous food resources.

To test for both direct and interactive effects of egg energy and exogenous food on larval growth and development, we reared larvae from 3 geminate species of echinoids in the genus Echinometra that differ in egg energy at a range of food levels. Geminate species are sister taxa formed when previously continuous marine species were separated before or during the raising of the Panamanian Isthmus and coincident closure of the Central American Seaway (CAS) 2 to 4 million years ago (Mya) (Duque-Caro 1990, Keigwin 1982). Based on cytochrome oxidase I (COI) sequence data, divergence between the sympatric tropical western Atlantic (WA) members occurred 1.27 to 1.62 Mya (McCartney et al. 2000). Divergence between the most recent common ances- 
tor of the WA species and E. vanbrunti (tropical eastern Pacific, EP) likely occurred around the time of final closure of the CAS 3.2 Mya. Two of the species, E. lucunter and E. viridis, occur in the WA; the third, E. vanbrunti, is found in the EP. As found for several other geminate species pairs in different phyla, egg size is larger in species from the WA than the EP (Lessios 1990, Jackson \& Herrera 1999, Moran 2004, McAlister 2008, McAlister \& Moran 2012), and egg energy content is greater (McAlister \& Moran 2012). The larger size of eggs of WA species has been attributed to selection for increased maternal investment in per-egg energy in the comparatively food-poor WA (Lessios 1990, Jackson \& Herrera 1999, Moran 2004); therefore, we chose experimental food levels that mimicked the contrasting natural food levels in the 2 oceans. Adults of Echinometra are readily collected, their larvae are amenable to laboratory culture, and their natural history has been well studied (Pearse 1969, Lessios 1990, Lessios \& Cunningham 1990, Palumbi \& Metz 1991, Ringwood 1992, McCartney et al. 2000, Geyer \& Palumbi 2003, McAlister 2008, Geyer \& Lessios 2009, McAlister \& Moran 2012).

\section{MATERIALS AND METHODS}

\section{Study taxa}

Members of each of the 3 species in the Echinometra geminate complex were collected in the Republic of Panama in July and August 2011. The 3 species in this study occur in coastal marine waters of the tropical EP (E. vanbrunti) or WA (E. lucunter, E. viridis) and are members of a geminate species group (Jordan 1908, Lessios 1990, McCartney et al. 2000). E. viridis and E. lucunter were collected from coral reef and rubble habitats near the Galeta Marine Laboratory of the Smithsonian Tropical Research Institute (STRI) near Colon, Panama; E. vanbrunti were collected using SCUBA from rocky subtidal marine habitats off Isla Taboguilla near the Naos Island Laboratories (STRI). All individuals were transported live to the Naos Island Laboratories where they were maintained in outdoor aquaria supplied with flowthrough seawater.

\section{Obtaining, measuring, and sampling gametes}

Gametes were obtained by injection with $0.5 \mathrm{M}$ $\mathrm{KCl}$. To obtain a broad genetic sample of the popula- tion, and because the biochemical analyses required large numbers of larvae, we collected gametes from multiple males and females: 12 females and 8 males of Echinometra viridis, 14 females and 7 males of $E$. lucunter, and 6 females and 6 males of E. vanbrunti. Spawning females were inverted separately over small cups filled with seawater. Concentrated sperm was collected from males and kept on ice in individual microcentrifuge tubes until needed $(<2 \mathrm{~h})$. Eggs of each female were placed in filtered seawater on glass slides under cover slips resting on clay feet to prevent flattening, and photographed under $100 \times$ magnification on a Wild M20 microscope outfitted with a Canon 7D DSLR camera. We used ImageJ software (National Institutes of Health) to collect the longest axis diameter and its perpendicular from 10 eggs from each female. Egg volume was calculated as for a prolate spheroid.

For biochemical sampling of each species, eggs from all females were combined and 9 replicate samples of known egg number (1500 to 5000 per sample) were taken: 3 samples each for protein and carbohydrate assays, and 3 samples for lipid profiling. Egg samples were frozen at $-80^{\circ} \mathrm{C}$ at STRI and transported to Clemson University on dry ice for biochemical analysis (see 'Egg biochemistry' below). After samples were taken, the remaining eggs of each species were fertilized with a dilute suspension of conspecific sperm from all males combined. For each species, fertilized eggs were then subdivided into 3 large 201 cultures and kept at ambient seawater temperature.

To ensure that only normally developing larvae were included in the feeding experiment, actively swimming larvae were collected from the top of all 3 cultures per species after $24 \mathrm{~h}$ and placed into $11 \mathrm{con}-$ tainers (9 per species) at a density of 1 larva $\mathrm{ml}^{-1}$. Larvae were fed the unicellular alga Dunaliella tertiolecta at 1 of 3 food levels: 10 (high), 0.3 (medium), and 0.1 (low) cells $\mu l^{-1}$. Each food treatment was replicated 3 times for each species. The algal concentration of the high food treatment was chosen because it is a satiating level of food for Echinometra larvae (McAlister 2008) and therefore food availability would not limit growth or development in this treatment. The medium and low concentrations were selected based on average yearly concentrations of phytoplankton cells reported from the habitat of $E$. vanbrunti in the EP (medium) and the WA range of $E$. viridis and E. lucunter (low) (D'Croz \& Robertson 1997). Although the food levels used in this study mimicked natural phytoplankton concentrations found in the 2 oceans, the natural diets of these lar- 
vae are unknown, both in terms of their complexity and quality. While a monoculture diet is certainly unlikely to be the natural state, this diet allowed us to closely control the concentration of food particles in replicate cultures. Larvae were fed daily starting at $48 \mathrm{~h}$ post-fertilization. The water in all cultures was changed daily using filtered seawater (using $1 \mu \mathrm{m}$ 'absolute' rated filters), and containers were constantly stirred at $\sim 10$ strokes per min with acrylic paddles to homogenize food within each culture and to keep larvae in suspension (Strathmann 1987). The 27 cultures were maintained at $28^{\circ} \mathrm{C}$ in a recirculating water bath and kept indoors at the Naos Island Laboratories.

\section{Larval growth}

To estimate growth of larvae, 10 larvae from each culture were immobilized with a dilute $(<10 \%)$ solution of buffered formalin on Days 2, 5, 8, 11, 15, 18, 21 , and 24 post-fertilization. Larvae were placed on glass microscope slides and covered with a glass slip supported on clay feet. To measure larval size, we used a camera lucida, digitizing tablet, and rotary encoder to obtain $x, y$, and $z$ coordinates (after McEdward 1985) for estimating body length and rudiment size of 5 of the 10 larvae collected from each culture at each time point (10 larvae were sampled because not all larvae on the slide were likely to be in the correct orientation for measurement). Body length was measured from the posterior tip of the larva to the tip of the oral hood, and the longest axis of the juvenile rudiment (parallel with the larval anterior-posterior axis) was used to estimate rudiment size. Coordinates were entered into the geometric formula for determining the distance between 2 points in 3dimensional space using MS Excel.

\section{Developmental staging}

Echinoid pluteus larvae develop through a series of well described developmental stages (Pearse \& Cameron 1991) defined by the emergence of successive pairs of skeletal arm rods followed by formation of a juvenile rudiment (Mortensen 1921). To estimate length of development, we staged the 10 larvae we sampled from each culture on each measurement day. Each larva was staged as either: 4 -armed pluteus (4), 6-armed pluteus (6), 8-armed pluteus (8), 8armed pluteus with a rudiment (R), or metamorphically competent (MC). A culture was determined to be at a particular stage when $>50 \%$ of the individual larvae from that culture had reached that stage. Larvae were staged as $R$ if the vestibule had contacted the hydrocoel. Within the temporal resolution $(\sim 3 \mathrm{~d}$ between samplings) of our study, most larvae in a culture staged as $\mathrm{R}$ had well developed rudiments. Larvae that were staged as $\mathrm{MC}$ had begun resorption of larval arms; pedicellariae were usually present at this stage. To confirm that larvae in a culture staged as $\mathrm{MC}$ were in fact capable of metamorphosis, we introduced natural reef rock into MC cultures and examined them after $24 \mathrm{~h}$ for metamorphosed larvae. Due to time constraints, the experiment was ended after $24 \mathrm{~d}_{i}$ not all cultures from each species had reached metamorphic competence at this time, but all had reached the rudiment $(\mathrm{R})$ stage. Therefore, in order to make statistical comparisons among all 3 species and food levels, we used the duration of development only to the $\mathrm{R}$ stage for analyses.

\section{Egg biochemistry}

To determine egg energy of each species, we measured protein, carbohydrate, and lipid content. These 3 biochemical constituents are the primary energetic reserves contained in the eggs of marine invertebrates (Holland \& Gabbott 1971, Turner \& Rutherford 1976, Turner \& Lawrence 1979, McClintock \& Pearse 1986, Wourms 1987, George et al. 1990, Jaeckle 1995, Thiyagarajan \& Qian 2003, Moran \& Manahan 2003, 2004, Sewell 2005, Meyer et al. 2007, Byrne et al. 2008, Prowse et al. 2008). Protein was assayed using a micro-modification of the Lowry Protein Assay (Lowry et al. 1951, McAlister \& Moran 2012), the Micro BCA Protein Assay Kit (Pierce). Carbohydrate content was assayed using a potassium ferricyanide sodium carbonate/cyanide reducing reaction (Folin \& Malmros 1929, Holland \& Gabbott 1971, McAlister \& Moran 2012). Lipid classes were separated via thin-layer chromatography (TLC) and the amounts of each type were determined using an IATROSCAN Mark-VI flame ionization detector (FID) (Moran \& Manahan 2003, 2004).

For each species, we measured total protein and total carbohydrate. Like eggs of other planktotrophic echinoderms (Sewell 2005, Meyer et al. 2007, Byrne et al. 2008, Prowse et al. 2008), detectable lipid classes in eggs of Echinometra included phospholipids, triacylglycerols, and sterol lipids; we calculated total lipid by summing these lipid classes. To determine total biochemical content per egg 
(ng $\mathrm{egg}^{-1}$ ), we summed per egg averages of protein, lipid, and carbohydrate. To calculate egg energy $\left(\mathrm{mJ} \mathrm{egg}^{-1}\right)$, we multiplied the total amount of each constituent by its oxyenthalpic energy equivalent (39.5 $\mathrm{kJ} \mathrm{g}^{-1}$ for lipid, $24 \mathrm{~kJ} \mathrm{~g}^{-1}$ for protein, and $17.5 \mathrm{~kJ}$ $\mathrm{g}^{-1}$ for carbohydrate; Gnaiger 1983) and summed the resultant values.

\section{Statistical analysis}

We tested for differences in egg size (volume) between species using 1-way analysis of variance (ANOVA) followed by post-hoc multiple comparisons (Tukey's HSD) using IBM SPSS Statistics (v. 20). Egg volumes were natural $\log (\mathrm{ln})$ transformed prior to analysis to meet the assumptions of normality; normality was tested using the Shapiro-Wilk's test. Based on the results of previous research (Lessios 1990, McAlister 2008, McAlister \& Moran 2012), our a priori expectation was that the eggs of Echinometra viridis would be larger than those of E. lucunter, which would in turn be larger than those of E. vanbrunti, and thus our analyses were 1-tailed.

To assess differences in larval size at the $\mathrm{R}$ stage (reached on different days for different species-byfood combinations, see Fig. 1), we tested for the effect of Species, Food, and the interaction between them (Species $\times$ Food) on body length using a 2tailed 2-way ANOVA (PROC MIXED, SAS Institute) (Littell et al. 1996) followed by post-hoc multiple comparisons (Tukey-Kramer) using SAS (v. 9.3). Midline body length values were used as the dependent variable and were ln-transformed before analysis to meet the assumptions of normality; normality was tested using the Shapiro-Wilk's test in SAS (PROC UNIVARIATE). Species, Food, and Species $\times$ Food were coded as fixed effects. Culture replicate (Culture) was coded as a random effect and was nested within the interaction of Species $\times$ Food. Degrees of freedom were calculated using the DDFM = SATTERTH (Satterthwaite approximation) option in SAS. As we were specifically interested in the interactive effects of Species and Food on larval growth, we tested for differences in the least square means of the Species $\times$ Food interaction term.

To determine whether food level or species had significant effects on growth, we conducted a repeated measures ANOVA (PROC MIXED, SAS Institute) across the 3 species and 3 food levels using the natural log-transformed midline body length as the dependent variable. We performed post-hoc multiple comparisons using Tukey-Kramer (in PROC
MIXED) and tested for data normality using the Shapiro-Wilk's test (in PROC UNIVARIATE) using SAS (v. 9.3). For each species and food combination, we utilized data from all measurement days up to and including the day at which rudiment presence was attained. We tested for significant effects of species (Species), development day post-fertilization (Day), food level (Food), and culture replicate (Culture). Species, Day, Food, and the 2- and 3-way interaction terms among these variables were coded as fixed effects. Culture was nested within the 2-way interaction term, Species $\times$ Food, and was coded as a random effect. Day was coded as a repeated measure with Culture as the subject. The covariance structure of the R matrix was specified as Compound Symmetry (CS) (constant variance and covariance) and degrees of freedom were calculated using DDFM = BW (Between-Within), the default option for repeated measures ANOVAs in SAS.

To determine the effect of food treatment and species on length of development to the R stage, we used log-linear analysis for 3-way contingency tables (Cords 1986, Brunkow \& Collins 1996, Ebert et al. 1999, Barnes \& Crook 2001; calculator available online at http://vassarstats.net/abc.html). Loglinear analysis is based on individual counts and can thus test for dependent effects among variables using data that are categorical (Fienberg 1977). We constructed separate contingency tables for each species on Days 11 and 15 post-fertilization, the 2 days on which there were R-stage larvae collected from every Species $\times$ Food combination. In the contingency tables, columns were designated as the 3 food treatments (high, medium, low) and rows were designated as stage (presence or absence of the R stage) in larvae from each Species $\times$ Food combination; the number of larvae with rudiments present were entered into one row and the number without in another. For each day, $G$-test statistics $\left(G^{2} \approx \chi^{2}\right)$ were calculated for the 3 -way (Species $\times$ Food $\times$ Stage) and 2-way (Species $\times$ Stage and Food $\times$ Stage) interactive effects.

\section{RESULTS}

Initial mean $( \pm 1 \mathrm{SE})$ egg volumes were 0.44 (0.01) for Echinometra viridis, 0.30 (0.01) for E. lucunter, and $0.21(0.01) \mathrm{nl}$ for E. vanbrunti. One-way ANOVA of ln-transformed egg volumes found significant differences (all p-values < 0.001) in egg volume among species and for each between-species comparison in post-hoc tests. Transformed (ln) egg volumes were normally distributed (Shapiro-Wilk's $W$-statistic $=$ 
Table 1. Echinometra viridis, E. lucunter, and E. vanbrunti. Egg physical, biochemical, and energetic characteristics $( \pm 1 \mathrm{SE})$ : volume (nl), biochemical constituent contents $\left(\mathrm{ng} \mathrm{egg}^{-1}\right.$ ) and energy $\left(\mathrm{mJ} \mathrm{egg}^{-1}\right)$. Triacyl.: triacylglycerols; Phospho.: phospholipids

\begin{tabular}{|c|c|c|c|c|c|c|c|c|c|}
\hline Species & $\begin{array}{c}\text { Egg } \\
\text { volume } \\
\text { (nl) }\end{array}$ & $\begin{array}{l}\text { Triacyl. } \\
\left(\text { ng egg }^{-1}\right)\end{array}$ & $\begin{array}{c}\text { Sterols } \\
\left(\text { ng egg }^{-1}\right)\end{array}$ & $\begin{array}{l}\text { Phospho. } \\
\left(\text { ng egg }^{-1}\right)\end{array}$ & $\begin{array}{c}\text { Total } \\
\text { lipid } \\
\left({\left.\text { ng } \text { egg }^{-1}\right)}\right.\end{array}$ & $\begin{array}{c}\text { Total } \\
\text { protein } \\
\left(\text { ng } \operatorname{egg}^{-1}\right)\end{array}$ & $\begin{array}{c}\text { Total } \\
\text { carbohydrate } \\
\left(\mathrm{ng} \mathrm{egg}{ }^{-1}\right)\end{array}$ & $\begin{array}{c}\text { Summed } \\
\text { constituents } \\
\left(\mathrm{ng} \mathrm{egg}{ }^{-1}\right)\end{array}$ & $\begin{array}{c}\text { Total } \\
\text { energy } \\
\left(\mathrm{mJ} \mathrm{egg}^{-1}\right)\end{array}$ \\
\hline E. viridis & $0.44(0.01)$ & $8.3(0.6)$ & $0.8(0.1$ & $8.4(1.4)$ & $17.5(2.1)$ & $53.9(0.0)$ & $3.0(0.0)$ & 74.4 & 2 \\
\hline E. lucunter & $0.30(0.01)$ & $7.5(0.1)$ & $0.7(0.0)$ & $6.9(0.5)$ & $15.1(0.6)$ & $40.0(0.0)$ & $1.0(0.0)$ & 56.1 & 1.6 \\
\hline E. vanbrunti & $0.21(0.01)$ & $3.4(0.1)$ & $0.6(0.0)$ & $4.3(0.5)$ & $8.3(0.6)$ & $27.5(0.0)$ & $2.0(0.0)$ & 37.8 & 1 \\
\hline
\end{tabular}

0.979; p-value $=0.787$ ). Mean measures of egg biochemistry and calculations of egg energy corresponded with egg size in this study; larger eggs contained more biochemical constituents and more energy than smaller eggs. Mean measures of egg volume, egg biochemistry, and calculations of per egg total energy are given in Table 1.

We assayed larval development and growth in our experiment through 2 measures: larval size (midline body length) at, and length of development (time in d) to, the R stage. We found significant differences in larval size at the $\mathrm{R}$ stage that were due to the main effects of species (egg size), food level, and the interaction between the two. We found similar results using both an ANOVA model that contained larval size data only from the development day at which the $\mathrm{R}$ stage was attained (Table 2), and a repeated measures ANOVA that incorporated measures of larval size from all developmental days up to and including the R stage (Table 3).

Growth over time and size (ln midline body length) at the $\mathrm{R}$ stage of each species at the 3 food levels is shown in Fig. 1. The ANOVA testing for differences in larval size at the $\mathrm{R}$ stage showed significant effects of Species and Food, as well as a significant Species $\times$ Food interaction. lntransformed body length data were normally distributed (Shapiro-Wilk's $W$-statistic $=0.9892 ;$ p-value $=0.4666$ ) . Testing for differences of the least square means of the Species $\times$ Food interaction showed significant effects of Food on body length for Echinometra vanbrunti (Table 2); at the R stage, high-food larvae were larger than medium-food and low-food larvae. There was also a significant difference $(p$-value $=0.0455)$ between $E$. vanbrunti and $E$. viridis larvae in the high-level food treatments (Table 2). High-food E. vanbrunti attained greater body length than E. viridis, despite having started from much smaller eggs (Table 1). However, greater length in $E$. vanbrunti was attained only after 4 additional days of development; R stage was reached on Day 15 for E. vanbrunti vs. Day 11 for E. viridis. All other multiple com- 
Table 3. Echinometra viridis, E. lucunter, and E. vanbrunti. Repeated measures ANOVA of larval size over time. Dependent variable is natural log-transformed measures of midline body length. Day was coded as a repeated measure with Culture nested in Species $\times$ Food as the subject. df: degrees of freedom (numerator, denominator). Only significant (or marginally significant) Species $\times$ Day $\times$ Food multiple comparison adjusted p-values (Adj. Pr $>|t|$ ) are listed. Values in bold are statistically significant $(\mathrm{p}<0.05)$

\begin{tabular}{|c|c|c|c|}
\hline Main effects & df & $F$ & $\operatorname{Pr}>F$ \\
\hline \multicolumn{4}{|l|}{ Effect } \\
\hline$\overline{\text { Species }}$ & 2,18 & 20.10 & $<0.0001$ \\
\hline Day & 7,76 & 795.53 & $<0.0001$ \\
\hline Food & 2,18 & 56.41 & $<0.0001$ \\
\hline Species $\times$ Food & 4,18 & 6.80 & 0.0016 \\
\hline Day $\times$ Food & 9,76 & 5.46 & $<0.0001$ \\
\hline Species $\times$ Day & 9,76 & 10.48 & $<0.0001$ \\
\hline Species $\times$ Day $\times$ Food & 14,76 & 2.05 & 0.0243 \\
\hline Covariance parameter estimate & & $Z$ & $\operatorname{Pr} Z$ \\
\hline Culture (Species × Food) & & 1.45 & 0.0740 \\
\hline Differences of least square means & df & $t$ & Adj. $\operatorname{Pr}>|t|$ \\
\hline 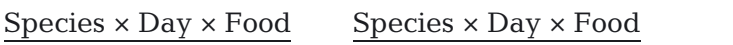 & & & \\
\hline E. vanbrunti $\times 15 \times$ High $\overline{\text { E. vanbrunti } \times 24 \times \text { Low }}$ & 14,76 & 5.00 & 0.0030 \\
\hline E. vanbrunti $\times 15 \times$ High E. vanbrunti $\times 18 \times$ Medium & 14,76 & 4.82 & 0.0056 \\
\hline E. vanbrunti $\times 15 \times$ High E. viridis $\times 11 \times$ High & 14,76 & 4.15 & 0.0500 \\
\hline E. vanbrunti $\times 15 \times$ High $E$. viridis $\times 15 \times$ Low & 14,76 & 4.70 & 0.0084 \\
\hline E. vanbrunti $\times 15 \times$ High $E$. viridis $\times 15 \times$ Medium & 14,76 & 5.48 & 0.0005 \\
\hline
\end{tabular}

parisons were not significant (adjusted p-values ranged from 0.1614 to 1.0000$)$.

The repeated-measures ANOVA showed similar significant main effects of Species and Food, as well as Day on growth (dependent variable was lntransformed midline body length; Table 3). These data were normally distributed (Shapiro-Wilk's $W$ statistic $=0.9846 ;$ p-value $=0.3263$ ). All 2-way and 3way main effect interaction terms were also significant. Culture vessel, nested in Species $\times$ Food, did not have a significant effect on growth. Inspection of the differences of the least square means for Species $\times$ Day $\times$ Food (Table 3) revealed significant differences among Echinometra vanbrunti larvae and a marginally significant difference $(p$-value $=$ $0.0500)$ between high-food $E$. vanbrunti and high-food $E$. viridis that matched the results obtained with the size at stage ANOVA described above (Table 2). In this analysis, all other multiple comparisons were not significant (adjusted p-values ranged from 0.4006 to 1.0000 ).

The differences between the least square means of larval size from each
Species $\times$ Food combination (or comparable Species $\times$ Day $\times$ Food combinations in Table 3) revealed patterns of interaction between these variables that were species-specific. In the 2 species with larger eggs, Echinometra viridis and E. lucunter, we found no significant differences in size at the $\mathrm{R}$ stage among the 3 food treatments (Fig. 1a,b, Tables 2 \& 3). However, in the species with the smallest eggs, E. vanbrunti, we found that larvae fed high levels of food were significantly larger than those fed medium or low levels (Fig. 1c, Tables 2 \& 3).

Log-linear analysis of 3-way contingency tables found significant differences in length of development to the $\mathrm{R}$ stage due to both food treatment and species, and differences were found for both Days 11 and 15. Rudiments were present in some larvae from all 3 species and in some food treatments by Days 11 and/ or 15 post-fertilization. There were significant differences in the proportions of larvae that had reached the R stage on both Days 11 and 15 that were associated with species (egg size), food treatment, and their interaction (Table 4). Results of the G-tests for 3-way and 2-way interactive effects are given in Table 4 . Fig. 1a-c shows development time to the R stage for each Species $\times$ Food combination. For Echinometra viridis, the species with the largest egg, high-food cultures reached the $\mathrm{R}$ stage on Day 11, whereas

Table 4. Echinometra viridis, E. lucunter, and E. vanbrunti. Effects on length of development to the rudiment stage of Food, Species, and their interaction. Stage $=$ proportion of larvae with rudiments; Food $=$ high, medium, or low (see Table 2 for details); Species $=$ Echinometra viridis, $E$. lucunter, or E. vanbrunti. $G^{2}=G$ test statistic $\left(\approx \chi^{2}\right)$, df $=$ degrees of freedom. Values in bold are statistically significant $(\mathrm{p}<0.05)$

\begin{tabular}{|lrrrrr|}
\hline \multirow{2}{*}{ Interaction } & \multicolumn{2}{c}{ Day 11} & \multicolumn{2}{c|}{ Day 15} & $\mathrm{~d}$ \\
& $G^{2}$ & $\mathrm{p}$ & \multicolumn{1}{c}{$G^{2}$} & $\mathrm{p}$ & \\
\hline Stage $\times$ Food $\times$ Species & 119.02 & $\mathbf{2 0 . 0 0 0 1}$ & $130.12<\mathbf{0 . 0 0 0 1}$ & 12 \\
Stage $\times$ Food & $64.78<\mathbf{0 . 0 0 0 1}$ & 53.46 & $<\mathbf{0 . 0 0 0 1}$ & 2 \\
Stage $\times$ Species & 28.92 & $<\mathbf{0 . 0 0 0 1}$ & 43.44 & $<\mathbf{0 . 0 0 0 1}$ & 2 \\
\hline
\end{tabular}




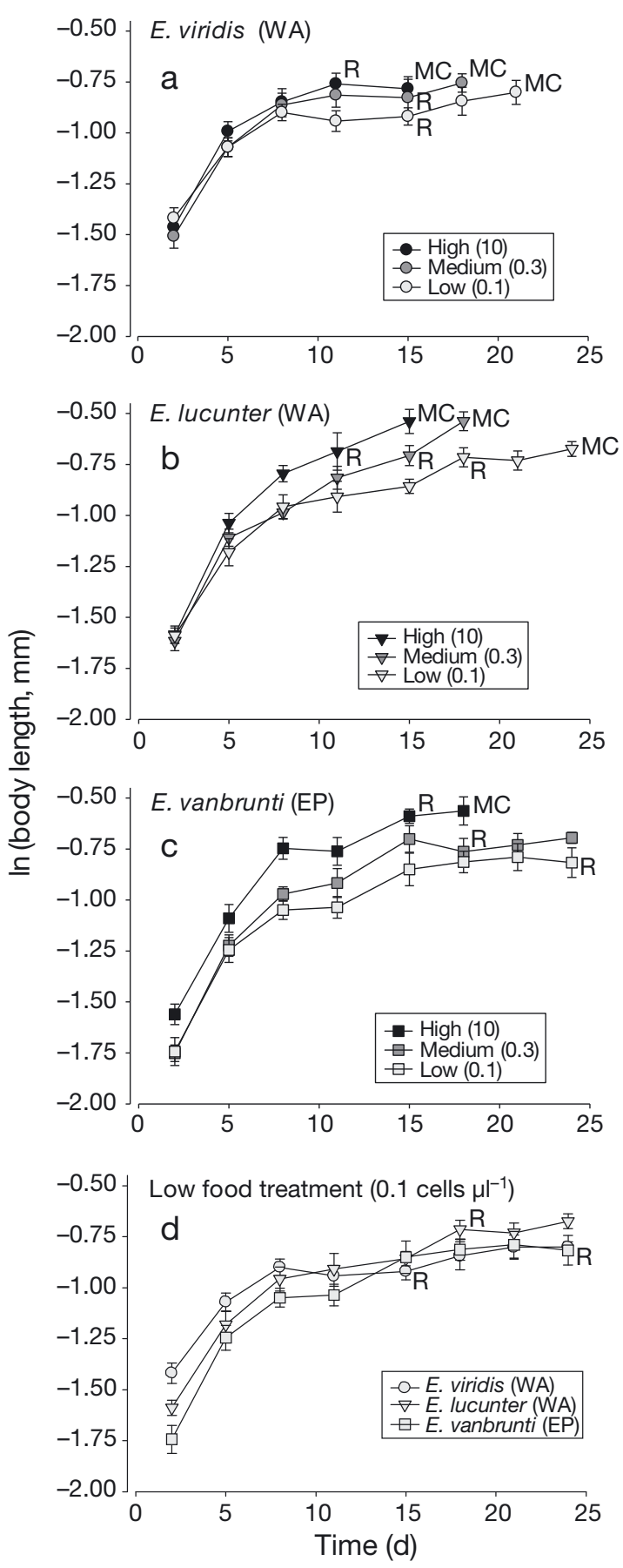

Fig. 1. Echinometra viridis, E. lucunter, and E. vanbrunti. Mean $( \pm 1 \mathrm{SE})$ natural log-transformed midline body lengths for larvae fed the high level (10 algal cells $\mu^{-1}$, black symbols), the medium level ( 0.3 algal cells $\mu l^{-1}$, dark grey symbols) and the low level food treatment $\left(0.1\right.$ algal cells $\mu l^{-1}$, light grey symbols) over time. Standard errors were calculated across replicate cultures $(\mathrm{n}=3)$ for each Species $\times$ Food combination. (a) E. viridis (western Atlantic, WA), (b) E. lucunter (WA), (c) E. vanbrunti (eastern Pacific, EP). (d) Results for low food (0.1 algal cells $\mu \mathrm{l}^{-1}$ ) larvae of (O) $E$. viridis, $(\nabla)$ E. lucunter, and $(\square)$ E. vanbrunti. Letters indicate developmental stage attainment: $\mathrm{R}=$ juvenile rudiment, $\mathrm{MC}=$ metamorphic competence medium- and low-food cultures reached R on Day 15 (Fig. 1a). High- and medium-food cultures of $E$. lucunter reached the $\mathrm{R}$ stage on the same days as their E. viridis counterparts, Days 11 and 15, respectively. However, larvae of low-food E. lucunter did not reach the R stage until Day 18 (Fig. 1b), and development was even longer in $E$. vanbrunti, the species with the smallest egg. High-food E. vanbrunti cultures reached the $\mathrm{R}$ stage on Day 15, whereas medium- and low-food cultures did not reach R until Days 18 and 24, respectively (Fig. 1c). Both within and across food regimes, we found that length of development increased with decreasing egg energy among Echinometra (see Fig. 1d for lowfood larvae of all species).

\section{DISCUSSION}

Among 3 congeneric planktotrophic sea urchins with differing egg sizes, both the size of R-stage larvae and the length of development to the $R$ stage were associated with the amount of maternally provisioned energy in the egg and exogenous food availability. Likewise, we found a significant interaction between species and food availability, such that the growth and development of larvae from the species with the lowest-energy egg was the most strongly affected by food level. While not all cultures reached $\mathrm{MC}$ in the time frame of our experiments, for those that did (all except for medium- and low-food Echinometra vanbrunti), the effects of egg size and exogenous food were qualitatively similar (Fig. 1a,b). The relationship between egg energy and larval duration results fit with predictions stemming from life history models of the trade-off between egg energy (size) and length of development (Vance 1973a,b, Christiansen \& Fenchel 1979, Caswell 1981, Perron \& Carrier 1981, Grant 1983, Strathmann 1985, Roughgarden 1989, Havenhand 1995, Podolsky \& Strathmann 1996, McEdward 1997, Levitan 2000), and supports the idea that larger eggs may have evolved in part to buffer the developmental effects of low environmental food availability.

\section{Effects of egg energy on larval growth and development}

Previous tests of the relationships among egg energy and larval growth and development employed either broad phylogenetic comparisons among species with different egg sizes (similar to ours with 
Echinometra, but using more distantly related taxa), or an intraspecific, manipulative approach using blastomere separations and fusions (experimental embryology). The evidence for a negative relationship between egg size and developmental time from comparative studies using laboratory-reared larvae is not always strong (Emlet et al. 1987); however, there are many factors such as inconsistent rearing conditions, interspecific differences in size at metamorphosis, and other phylogenetic effects that could mask this relationship (Emlet et al. 1987, Herrera et al. 1996). When Emlet (1995) compared egg size with developmental time among 28 species of regular echinoids and corrected for different rearing temperatures, he found a significant relationship, suggesting that consistency in rearing conditions is important. Likewise, when the relationship between egg size and egg energy (energy density) varies among taxa (e.g. McEdward \& Carson 1987, McEdward \& Coulter 1987, McEdward \& Morgan 2001, McAlister \& Moran 2012), any underlying correlation between egg energy and length of development will be further obscured. Selection for increased fertilization success can also drive the evolution of large eggs independently of selection for shortened development (Levitan 2000).

We also found a significant effect of species on larval size at the $\mathrm{R}$ stage; the species with the lowestenergy (and smallest) eggs attained the largest sizes at $\mathrm{R}$ when averaged across all food treatments (Fig. 1, Table 2). Unlike developmental time, interspecific comparisons do not support the idea that egg size is related to size at metamorphosis in echinoids (Emlet et al. 1987). This is perhaps not surprising because the selective factors that govern success in the juvenile habitat are not likely to be the same as those in the plankton (Marshall 2008). In Echinometra, it is possible that because E. vanbrunti, the species with the smallest egg, occurs in the highly productive $\mathrm{EP}$, its larvae have a greater capacity to assimilate high levels of phytoplankton; alternatively, the juvenile habitat in the EP might select for larger size, perhaps because of differences in food availability or predation.

One experimental method that has been employed in echinoids to isolate the effects of egg energy from phylogenetic, maternal, and methodological effects is blastomere manipulation. In most echinoderms, because of their regulative development, half-, quarter-, and even double-sized eggs can develop normally (McEdward 1996). While these tests seem ideal in some respects, results are not always consistent: larvae from larger eggs develop more rapidly than their half-sized siblings in many studies (Sinervo \& McEdward 1988, Levitan 2000, Alcorn \& Allen 2009, Allen 2012) but not all (Hart 1995, Emlet \& HoeghGuldberg 1997, Allen et al. 2006), and larvae from half-sized eggs resulted in smaller juveniles in some species (Hart 1995, Allen et al. 2006, Alcorn \& Allen 2009, Allen 2012) but not others (Sinervo \& McEdward 1988, Allen 2012). Differences among blastomere separation studies may be due in part to the characteristic egg size of a particular species. Under the assumption of an inversely proportional relationship between egg size and development time, length of development increases exponentially as egg energy decreases (Levitan 2000), a pattern which has been generally found in blastomere reduction experiments (Allen 2012). Thus, given the low temporal resolution and high noise in many larval studies, the effect of blastomere reductions on the length of development may be most readily detectable in species whose eggs are on the small end of the planktotrophic spectrum (Allen 2012). Likewise, the responses of species to the halving of egg energy may be modulated by species-specific differences in the maternal, genetic, and epigenetic background of regulation of larval development.

\section{Interactive effects of food and egg energy on development and size}

In addition to species-dependent effects on the length of larval development and size at the R stage, we also found a significant interaction between species and food level that was associated with egg energy: across species, larvae receiving the highest food ration grew more and developed more rapidly than larvae receiving lower food rations, but this effect was more pronounced for the species with smaller eggs (Fig. 1, Tables 2, 3, \& 4). Echinometra vanbrunti, the species with the smallest egg, was the only species for which food level significantly affected size at $R_{i}$ for the other 2 species, there was no effect (Table 2). Larvae of E. vanbrunti also extended their development relative to the other 2 species much more in the low than in the high and medium food treatments. In the high and medium treatments, the development of $E$. vanbrunti was delayed relative to the other 2 species by 3 or $4 \mathrm{~d}$, while in the low treatment, development was delayed by $6 \mathrm{~d}$ compared to E. lucunter and by $9 \mathrm{~d}$ relative to $E$. viridis (Fig. $1 \mathrm{~d}$ ).

While the effects of egg energy on the length of larval development and larval growth have received 
considerable attention, only a handful of studies have sought evidence for an interaction between egg energy and exogenous food availability, and none have, to our knowledge, used an interspecific approach with sister taxa. Alcorn \& Allen (2009) and Allen (2012) tested for interactions between food level and egg size on size and age at metamorphosis using blastomere separations in 5 species of echinoids, with variable results: 2 species showed significant interactions for both size and age at metamorphosis (Strongylocentrotus droebachiensis and Echinarachnius parma), 1 showed significant interactions for size but not age (Arbacia punctulata), 1 showed significant interactions for age with no data for size (S. purpuratus), and for 1 species, Dendraster excentricus, egg size and food ration did not significantly interact for age or size at metamorphosis. One likely explanation for these differences is that interactions could be masked by species-specific differences in the maternal, genetic, and epigenetic background of regulation of larval development, making it difficult to compare across distantly related taxa if egg energy does not evolve in isolation from other life-history traits. Another explanation might be that in order to have the statistical power to detect interactions, food levels must be carefully selected such that there are large differences in physiological response. In the present study, our low and medium food level treatments were chosen to match phytoplankton concentrations in the EP and WA, and the low food treatment, in particular, was 5 to $10 \times$ lower than the lowest food treatments commonly used in other studies (e.g. McAlister 2007, 2008, Alcorn \& Allen 2009, Allen 2012).

Both previous studies with blastomere separations (Alcorn \& Allen 2009, Allen 2012) and our work with Echinometra suggest that among planktotrophs, large, energy-rich eggs act to reduce a larva's reliance on exogenous food resources. However, selection for increased egg energy to offset a poor larval feeding environment or high larval mortality will also act on other aspects of larval physiology and morphology, so it is essential to have some understanding of the larval environment. In the present study, we compared 3 closely related species with different egg sizes that occur in distinctly different food environments. Egg size is consistently larger in the WA member of geminate species in multiple phyla, including echinoderms (Lessios 1990, Jackson \& Herrera 1999, Moran 2004), and egg energetic content among geminate Echinometra spp. follows a similar pattern (McAlister \& Moran 2012). These differences have been attributed to contrasting larval feeding environment between the WA and the EP (Lessios 1990, Moran 2004). The EP is characterized by strong, seasonal upwelling that produces variable yet predictably high phytoplankton levels, whereas the WA experiences little upwelling, has low primary production, and is thus constantly nutrient poor and low in phytoplankton (Glynn 1982, Keigwin 1982).

Among the 3 species of Echinometra, the EP species had the lowest-energy eggs and was also the most strongly affected by food level. This provides support for other work with geminate species (Lessios 1990, Moran 2004, McAlister 2008, McAlister \& Moran 2012) suggesting that the larger eggs of WA species function to buffer the length of larval development and the size of competent larvae against the comparatively low food availability in that ocean. An additional insight provided by our feeding experiment is that growth of larvae from the 2 WA species appeared to be a relatively canalized process in which body and feeding structure sizes were regulated such that increasing levels of external food decreased length of development, but had little impact on larval size up to the R stage. Interestingly, E. lucunter grew to larger sizes after the $\mathrm{R}$ stage than $E$. viridis in all food treatments, which may indicate either that $E$. lucunter is better able to utilize external food, or that in the face of trade-offs, E. viridis makes different choices about when and/or where to invest food-derived energy, e.g. increasing the size of the juvenile rudiment at the expense of increasing larval body size upon reaching R. In E. vanbrunti, the EP species, larvae in the high food treatment showed both more rapid development to the $\mathrm{R}$ stage, and also greater size at that stage. These results suggest that larvae of E. vanbrunti, which develop from eggs comparable in size to some of the smallest eggs known among echinoids (McEdward \& Morgan 2001), may have a greater physiological capacity to rapidly utilize external food resources when present. The mechanisms driving this pattern of rapid growth may involve increased efficiency in food capture, digestion, and/or assimilation, and may serve an adaptive function in the highly variable phytoplankton food environment of the EP.

Acknowledgements. We thank R. Collin, H. Lessios, L. Geyer and the staff of the Naos Island Laboratories and Galeta Marine Laboratory of the Smithsonian Tropical Research Institute. We also thank S. Crickenberger and C. Genovese for their assistance with sea urchin collection and experimental maintenance. Funding was provided by National Science Foundation grant OCE-0850764 to A.L.M. 


\section{LITERATURE CITED}

Alcorn NJ, Allen JD (2009) How do changes in parental investment influence development in echinoid echinoderms? Evol Dev 11:719-727

Allen JD (2012) Effects of egg size reductions on development time and juvenile size in three species of echinoid echinoderms: implications for life history theory. J Exp Mar Biol Ecol 422-423:72-80

> Allen JD, Pernet B (2007) Intermediate modes of larval development: bridging the gap between planktotrophy and lecithotrophy. Evol Dev 9:643-653

> Allen JD, Podolsky RD (2007) Uncommon diversity in developmental mode and larval form in the genus Macrophiothrix (Echinodermata: Ophiuroidea). Mar Biol 151:85-97

Allen JD, Zakas C, Podolsky RD (2006) Effects of egg size reduction and larval feeding on juvenile quality for a species with facultative-feeding development. J Exp Mar Biol Ecol 331:186-197

Anger K (1995) Starvation resistance in larvae of a semiterrestrial crab, Sesarma curacaoense (Decapoda: Grapsidae). J Exp Mar Biol Ecol 187:161-174

> Barnes DKA, Crook AC (2001) Quantifying behavioural determinants of the coastal European sea urchin Paracentrotus lividus. Mar Biol 138:1205-1212

> Bertram DF, Strathmann RR (1998) Effects of maternal and larval nutrition on growth and form of planktotrophic larvae. Ecology 79:315-327

Bridges TS, Heppell S (1996) Fitness consequences of maternal effects in Streblospio benedicti (Annelida: Polychaeta). Am Zool 36:132-146

$>$ Brunkow PE, Collins JP (1996) Effects of individual variation in size on growth and development of larval salamanders. Ecology 77:1483-1492

Byrne M, Sewell MA, Prowse TAA (2008) Nutritional ecology of sea urchin larvae: influence of endogenous and exogenous nutrition on echinopluteal growth and phenotypic plasticity in Tripneustes gratilla. Funct Ecol 22: 643-648

> Caswell H (1981) The evolution of 'mixed' life histories in marine invertebrates and elsewhere. Am Nat 117: 529-536

> Christiansen FB, Fenchel TM (1979) Evolution of marine invertebrate reproductive patterns. Theor Popul Biol 16: 267-282

Collin R (2012) Nontraditional life-history choices: what can 'intermediates' tell us about evolutionary transitions between modes of invertebrate development? Integr Comp Biol 52:128-137

Cords M (1986) Interspecific and intraspecific variation in diet of two forest guenons, Cercopithecus ascanius and C. mitis. J Anim Ecol 55:811-827

D'Croz LD, Robertson DR (1997) Coastal oceanographic conditions affecting coral reefs on both sides of the Isthmus of Panama. Proc 8th Int Coral Reef Symp, Panama City 2:2053-2058

Duque-Caro H (1990) Major Neogene events in Panamic South America. In: Tsuchi R (ed) Pacific Neogene events. University of Tokyo Press, Tokyo, p 101-113

- Ebert TA, Dixon JD, Schroeter SC, Kalvass PE, Richmond NT, Bradbury WA, Woodby DA (1999) Growth and mortality of red sea urchins Strongylocentrotus franciscanus across a latitudinal gradient. Mar Ecol Prog Ser 190: 189-209

Eckelbarger KJ (1994) Diversity of metazoan ovaries and vitellogenic mechanisms: implications for life history theory. Proc Biol Soc Wash 107:193-218

Emlet RB (1995) Developmental mode and species geographic range in regular sea urchins (Echinodermata: Echinoidea). Evolution 49:476-489

Emlet RB, Hoegh-Guldberg O (1997) Effects of egg size on postlarval performance: experimental evidence from a sea urchin. Evolution 51:141-152

Emlet RB, McEdward LR, Strathmann RR (1987) Echinoderm larval ecology viewed from the egg. In: Jangoux $M$, Lawrence JM (eds) Echinoderm studies, Vol 2. AA Balkema, Rotterdam, p 55-136

Fienberg SE (1977) The analysis of cross-classified categorical data. MIT Press, Cambridge, MA

Folin P, Malmros K (1929) Blood sugar and fermentable blood sugar as determined by different methods. J Biol Chem 83:121-127

- George SB, Cellario C, Fenaux L (1990) Population differences in egg quality of Arbacia lixula (Echinodermata: Echinoidea): proximate composition of eggs and larval development. J Exp Mar Biol Ecol 141:107-118

> Geyer LB, Lessios HA (2009) Lack of character displacement in the male recognition molecule, bindin, in Atlantic sea urchins of the genus Echinometra. Mol Biol Evol 26: 2135-2146

Geyer LB, Palumbi SR (2003) Reproductive character displacement and the genetics of gamete recognition in tropical sea urchins. Evolution 57:1049-1060

Glynn PW (1982) Coral communities and their modifications relative to past and prospective Central American seaways. Adv Mar Biol 19:91-132

Gnaiger E (1983) Calculation of energetic and biochemical equivalents of respiratory oxygen consumption. In: Gnaiger E, Forstner H (eds) Polarographic oxygen sensors. Springer-Verlag, Berlin, p 337-345

Grant A (1983) On the evolution of brood protection in marine benthic invertebrates. Am Nat 122:549-555

Hadfield MG, Miller SE (1987) On developmental patterns of opisthobranchs. Am Malacol Bull 5:197-214

Hart MW (1995) What are the costs of small egg size for a marine invertebrate with feeding planktonic larvae? Am Nat 146:415-426

Havenhand JN (1995) Evolutionary ecology of larval types. In: McEdward LR (ed) Ecology of marine invertebrate larvae. CRC, Boca Raton, FL, p 79-122

Herrera JC, McWeeney SK, McEdward LR (1996) Diversity of energetic strategies among echinoid larvae and the transition from feeding to nonfeeding development. Oceanol Acta 19:313-321

Holland DL, Gabbott PA (1971) A micro-analytical scheme for the determination of protein, carbohydrate, lipid and RNA levels in marine invertebrate larvae. J Mar Biol Assoc UK 51:659-668

Jackson JBC, Herrera AH (1999) Adaptation and constraint as determinants of zooid and ovicell size among encrusting ascophoran cheilostome Bryozoa from opposite sides of the Isthmus of Panama. Proc 11th Int Bryozool Assoc Conf, Balboa, Republic of Panama, p 249-258

Jaeckle WB (1995) Variation in egg size, energy content, and composition of invertebrate eggs: correlates to the mode of larval development. In: McEdward LR (ed) Ecology of marine invertebrate larvae. CRC Press, Boca Raton, FL, p 49-77

Jordan DS (1908) The law of geminate species. Am Nat 42: $73-80$ 
Keigwin L (1982) Isotopic paleoceanography of the Caribbean and east Pacific: role of Panama uplift in Late Neogene time. Science 217:350-353

Knott KE, McHugh D (2012) Introduction to symposium: Poecilogony - a window on larval evolutionary transitions in marine invertebrates. Integr Comp Biol 52: $120-127$

- Lessios HA (1990) Adaptation and phylogeny as determinants of egg size in echinoderms from the two sides of the Isthmus of Panama. Am Nat 135:1-13

Lessios HA, Cunningham CW (1990) Gametic incompatibility between species of the sea urchin Echinometra on the two sides of the Isthmus of Panama. Evolution 44: 933-941

Levin LA, Bridges TS (1995) Pattern and diversity in reproduction and development. In: McEdward LR (ed) Ecology of marine invertebrate larvae. CRC, Boca Raton, FL, p 1-48

Levitan DR (2000) Optimal egg size in marine invertebrates: theory and phylogenetic analysis of the critical relationship between egg size and development time in echinoids. Am Nat 156:175-192

Littell RC, Milliken GA, Stroup WW, Wolfinger RD (1996) SAS system for mixed models. SAS Institute, Cary, NC

$>$ Lowry OH, Rosbrough NJ, Farr AL, Randall RJ (1951) The determination of protein in biologic samples. J Biol Chem 193:265-275

> Marshall DJ (2008) Transgenerational plasticity in the sea: context-dependent maternal effects across the life history. Ecology 89(2):418-427

Marshall DJ, Bolton TF, Keough MJ (2003) Offspring size affects the post-metamorphic performance of a colonial marine invertebrate. Ecology 84:3131-3137

McAlister JS (2007) Egg size and the evolution of phenotypic plasticity in larvae of the echinoid genus Strongylocentrotus. J Exp Mar Biol Ecol 352:306-316

McAlister JS (2008) Evolutionary responses to environmental heterogeneity in Central American echinoid larvae: plastic versus constant phenotypes. Evolution 62: 1358-1372

- McAlister JS, Moran AL (2012) Relationships among egg size, composition, and energy: a comparative study of geminate sea urchins. PLoS ONE 7:e41599

McCartney MA, Keller G, Lessios HA (2000) Dispersal barriers in tropical oceans and speciation in Atlantic and eastern Pacific sea urchins of the genus Echinometra. Mol Ecol 9:1391-1400

> McClintock JB, Pearse JS (1986) Organic and energetic content of eggs and juveniles of Antarctic echinoids and asteroids with lecithotrophic development. Comp Biochem Physiol A 85:341-345

McEdward LR (1985) An apparatus for measuring and recording the depth dimension of microscopic organisms. Trans Am Microsc Soc 104:194-200

McEdward LR (1986) Comparative morphometrics of echinoderm larvae. I. Some relationships between egg size and initial larval form in echinoids. J Exp Mar Biol Ecol 96:251-265

McEdward LR (1991) Interspecific relationships between egg size and the level of parental investment per offspring in echinoderms. Am Zool 31:105A

McEdward LR (1996) Experimental manipulation of parental investment in echinoid echinoderms. Am Zool 36:169-179

McEdward LR (1997) Reproductive strategies of marine benthic invertebrates revisited: facultative feeding by planktotrophic larvae. Am Nat 150:48-72

McEdward LR, Carson SF (1987) Variation in egg organic content and its relationship with egg size in the starfish Solaster stimpsoni. Mar Ecol Prog Ser 37:159-169

McEdward LR, Chia FS (1991) Size and energy content of eggs from echinoderms with pelagic lecithotrophic development. J Exp Mar Biol Ecol 147:95-102

> McEdward LR, Coulter LK (1987) Egg volume and energetic content are not correlated among sibling offspring of starfish: implications for life-history theory. Evolution 41: 914-917

> McEdward LR, Janies DA (1997) Relationships among development, ecology, and morphology in the evolution of Echinoderm larvae and life cycles. Biol J Linn Soc 60: 381-400

> McEdward LR, Morgan KH (2001) Interspecific relationships between egg size and the level of parental investment per offspring in echinoderms. Biol Bull 200:33-50

> Meyer E, Green AJ, Moore M, Manahan DT (2007) Food availability and physiological state of sea urchin larvae (Strongylocentrotus purpuratus). Mar Biol 152:179-191

Miller BA, Emlet RB (1999) Development of newly metamorphosed juvenile sea urchins (Strongylocentrotus franciscanus and S. purpuratus): morphology, the effects of temperature and larval food ration, and a method for determining age. J Exp Mar Biol Ecol 235:67-90

> Miner BG, McEdward LA, McEdward LR (2005) The relationship between egg size and the duration of the facultative feeding period in marine invertebrate larvae. J Exp Mar Biol Ecol 321:135-144

Moran AL (2004) Egg size evolution in tropical American arcid bivalves: the comparative method and the fossil record. Evolution 58:2718-2733

> Moran AL, Manahan DT (2003) Energy metabolism during larval development of two abalone species, Haliotis fulgens and H. sorenseni. Biol Bull 204:270-277

> Moran AL, Manahan DT (2004) Physiological recovery from prolonged 'starvation' in larvae of the Pacific oyster Crassostrea gigas. J Exp Mar Biol Ecol 306:17-36

Moran AL, McAlister JS (2009) Egg size as a life history character of marine invertebrates: Is it all it's cracked up to be? Biol Bull 216:226-242

Mortensen T (1921) Studies of the development and larval forms of echinoderms. G. E. C. Gad, Copenhagen

> Palumbi SR, Metz EC (1991) Strong reproductive isolation between closely related tropical sea urchins (genus Echinometra). Mol Biol Evol 8:227-239

Pearse JS (1969) Reproductive periodicities of Indo-Pacific invertebrates in the Gulf of Suez. II. The echinoid Echinometra mathaei (De Blainville). Bull Mar Sci 19: 580-613

Pearse JS, Cameron RA (1991) Echinodermata: Echinoidea. In: Giese AC, Pearse JS, Pearse VB (eds) Reproduction of marine invertebrates. Vol 6. Echinoderms and lophophorates. Boxwood Press, Pacific Grove, CA, p 513-662

Perron FE, Carrier RH (1981) Egg size distributions among closely related marine invertebrate species: are they bimodal or unimodal? Am Nat 118:749-755

Podolsky RD, Strathmann RR (1996) Evolution of egg size in free-spawners: consequences of the fertilization-fecundity trade-off. Am Nat 148:160-173

Prowse TAA, Sewell MA, Byrne M (2008) Fuels for development: evolution of maternal provisioning in asterinid sea stars. Mar Biol 153:337-349 
Ringwood AH (1992) Comparative sensitivity of gametes and early developmental stages of a sea urchin species (Echinometra mathaei) and a bivalve species (Isognomon californicum) during metal exposures. Arch Environ Contam Toxicol 22:288-295

Roughgarden J (1989) The evolution of marine life cycles. In: Feldman MW (ed) Mathematical evolutionary theory. Princeton University Press, Princeton, NJ, p 270-330

Sewell MA (2005) Utilization of lipids during early development of the sea urchin Evechinus chloroticus. Mar Ecol Prog Ser 304:133-142

Sewell MA, Manahan DT (2001) Echinoderm eggs: biochemistry and larval biology. In: Barker MF (ed) Echinoderms 2000: Proc 10th Int Conf, Dunedin. CRC Press, Boca Raton, FL, p 55-58

Sinervo B, McEdward LR (1988) Developmental consequences of an evolutionary change in egg size: an experimental test. Evolution 42:885-899

Strathmann RR (1985) Feeding and nonfeeding larval development and life-history evolution in marine invertebrates. Annu Rev Ecol Syst 16:339-361

Strathmann MF (1987) Reproduction and development of marine invertebrates of the northern Pacific coast. University of Washington Press, Seattle, WA

Strathmann RR, Vedder K (1977) Size and organic content of eggs of echinoderms and other invertebrates as related to developmental strategies and egg eating. Mar Biol 39: 305-309

Editorial responsibility: Steven Morgan,

Bodega Bay, California, USA
Thiyagarajan V, Qian PY (2003) Effect of temperature, salinity, and delayed attachment on development of the solitary ascidian Styela plicata (Lesueur). J Exp Mar Biol Ecol 290:133-146

Thorson G (1950) Reproduction and larval ecology of marine bottom invertebrates. Biol Rev Camb Philos Soc 25:1-45

Turner RL, Lawrence JM (1979) Volume and composition of echinoderm eggs: implications for the use of egg size in life history models. In: Stancyk SE (ed) Reproductive ecology of marine invertebrates. University of South Carolina Press, Columbia, SC, p 25-40

> Turner RL, Rutherford JC (1976) Organic, inorganic, and caloric composition of eggs, pentaculae, and adults of the brooding sea cucumber Cucumaria curata Cowles (Echinodermata: Holothuroidea). J Exp Mar Biol Ecol 24: $49-60$

Vance RR (1973a) On reproductive strategies in marine benthic invertebrates. Am Nat 107:339-352

Vance RR (1973b) More on reproductive strategies in marine benthic invertebrates. Am Nat 107:353-361

Wourms JP (1987) Oogenesis. In: Giese AC, Pearse JS, Pearse VB (eds) Reproduction of marine invertebrates. Vol 9, Seeking unity in diversity. Boxwood Press, Pacific Grove, CA, p 50-157

> Wray GA (1996) Parallel evolution of nonfeeding larvae in echinoids. Syst Biol 45:308-322

> Wray GA, Raff RA (1991) The evolution of developmental strategy in marine invertebrates. Trends Ecol Evol 6: 45-50

Submitted: December 14, 2012; Accepted: May 27, 2013 Proofs received from author(s): August 14, 2013 